Neuroepidemiology, 2013. 41(3-4): p. 156-60.

5. Wilartratsami, S., et al., Prevalence of primary spinal tumors: 15-year data from Siriraj Hospital. J Med Assoc Thai, 2014. 97 Suppl 9: p. S83-7.

6. Dang, L., et al., Primary tumors of the spine: a review of clinical features in 438 patients. J Neurooncol, 2015. 121(3): p. 513-20.
7. Maira, G., et al., Surgical treatment of cervical intramedullary spinal cord tumors. Neurol Res, 2001. 23(8): p. 835-42.

8. Lin, L., et al., Clinical therapeutic effect of surgery on upper cervical spinal cord tumors. Zhong Nan Da Xue Xue Bao Yi Xue Ban, 2015. 40(9): p. 1000-7.

\title{
ĐÁNH GIÁ ĐộC TÍNH BÁN TRƯỜNG DIỄN TRÊN CHỨC NĂNG GAN, THẬN CỦA VIÊN NANG CỨNG FUCOLEN SAU BÀO CHẾ TRÊN ĐộNG VẬT THỰC NGHIỆM
}

\author{
Trần Văn Thuấn ${ }^{1,2}$, Nguyễn Văn Khiêm ${ }^{3}$, \\ Trần Thị Thanh Hương ${ }^{1,2}$, Vũ Mạnh Tuấn ${ }^{2}$, Nguyễn Tiến Quang ${ }^{1}$
}

\section{TÓM TẮT}

Mục tiêu: Đánh giá độc tính bán trường diễn của viên nang cứng Fucolen trên hệ tạo huyết trên chuột nhắt trăng chủng Wistar. Đối tượng \& Phương pháp: nghiên cứu thực nghiệm trên 30 chuột trắng chủng Wistar. Kết quả: Sau khi sử dung thuốc 4 tuân, 8 tuần, 12 tuân thì sự thay đổi về các chỉ số chức năng gan (AST, $A L T)$ và creatinin trong máu chuột sử dung thuốc không có sự khác biệt có ý nghĩa thống kê với lô chuột ở nhóm chứng $(p>0,05)$. Không có sự thay đổi hình ảnh vi thể của gan, thận giữa chuột nhóm chứng và nhóm thực nghiệm. Kểt luận: Viên nang cứng Fucolen liêuu tưởng đương liều dự kiến lâm sàng $(0,48$ viên/ $\mathrm{kg} / \mathrm{ngày}$ uống liên tục 12 tuần không gây độc tính bán trường diễn trên gan và thận trên chuột thực nghiêm. Fucolen

Từ khóa: Độc tính bán trường diễn, Gan, Thận,

\section{SUMMARY}

EXAMINES THE SEMI-CHRONIC TOXICITIES OF FUCOLEN ON EXPERIMENTAL ANIMALS

Objective: To examines the semi-chronic toxicities of Fucolen on experimental animals. Subject and Method: semi-chronic toxicities of the Fucolen were evaluated on 30 Wistar mices on hematopoietic function. Results: after using Fucolen 4 weeks, 8 weeks and 12 weeks, the change of AST, $A L T$, creatinin in blood no different significants compare to control mice group $(p>0,05)$. There were also no changes in invitro of liver and kidney tisues. Conclusion: Fucolen is not toxic for mice and mice liver and kidney function. Keywords: Semi-toxicities; liver and kidney function, Fucolen

\footnotetext{
${ }^{1}$ Viện Ung thư quốc gia, Bệnh viện K

2Trường Đại học Y Hà Nội

${ }^{3}$ Viện Dược liệu

Chịu trách nhiệm chính: Trân Thanh Hương

Email: huongtran2008@gmail.com

Ngày nhận bài: 25.01.2021

Ngày phản biện khoa học: 22.3.2021

Ngày duyệt bài: 29.3.2021
}

\section{I.ĐĂT VẤN ĐỀ}

Fucoidan là môt hợp chất poly-saccharide có nguồn gốc tự nhiển được tìm thấy trong các loài tảo nâu khác nhau và ở một số động vật, được biết đến nhờ đặc tính chống ung thư của nó. Fucoidan có khả năng ức chế sự tăng trưởng, tăng sinh và di căn của các tế bào ung thư, loại bỏ độc tố tế bào dư thừa và loại bỏ các quá trình viêm.

Nấm chứa Lentinan kết hợp với chiết xuất rong biển tảo nâu chứa Fucoidan có tác dụng điều tiết đặc biêt đối với hề thống miễn dich, làm tăng cường hoạt động và duy trì hoạt động ở mức độ đỉnh của tế bào $T$, tế bào diêt tự nhiên và do vậy có các đặc tính cần thiết để ức chế sự phát triển của khối u. Lentinan có. Lentina cũng cung cấp $\beta$-glucan có thể ngăn ngừa các khối u phát triển mạch máu (xây dựng các mạch mới) cần thiết để cung cấp một khối u và nó có thể bắt đầu chương trình tự sát của tế bào (apoptosis). Trong quá hóa trị và/hoặc xạ trị, sự tạo máu xấu đi, Lentinan và Fucoidan có thể giúp củng cố các mô khỏe mạnh và do đó để bảo vệ chúng khỏi các tác dụng phụ [1], [2], [3].

Trển thế giới, các nghiển cứu nhằm kết hợp các thành phần khác nhau nhằm làm tăng tác dụng của sản phẩm trong hỗ trợ bệnh nhân ung thư đang là hướng đi mới. Việc kết hợp Fucoidan và Lentinan với tỷ lệ thích hợp được kỳ vọng sẽ phát huy được tối đa tác dụng hỗ trợ trong điêu trị ung thư cho bệnh nhân, dựa trên nguyên lý và cơ chế tác dụng đã được chứng minh của cá hai nguyên liệu này (liều tác dụng đơn chất của: Lentinan là $800 \mathrm{mg} / \mathrm{ngày}$, Fucoidan là $600 \mathrm{mg} / \mathrm{ngày}$ ). Việc kết hợp Lentinan và Fucoidan với tỷ lệ khác nhau đã được các nước phát triển như Nhật Bản, Đài Loan sử dung và cho ra đời các sản phẩm thương mại hổ trợ điều trị ung thư. Các sản phẩm này cũng đã được đánh giá là tốt trong 
việc hỗ trợ điều trị ung thư, nhưng giá thành sản phẩn còn rất cao so với thu nhập của người dân Việt Nam. Hiện nay, nước ta có nguồn nguyên liệu tự nhiên sẵn có như nấm hương với hàm lượng Lentinan rất cao, tảo nâu với hàm lượng Fucoidan cao đã nuôi trồng thành công trong nước [4], [5], [6], [7].

Fucolen là sản phẩm được xây dựng với tỷ lệ hàm lượng đủ lớn Lentinan kết hợp với liều thích hợp của Fucoidan, đã được đánh giá tính ổn định, chúng tôi thực hiện đề tài này nhằm đánh giá độc tính bán trường diễn của viên nang cứng Fucolen trên gan, thận trên mô hình động vật thực nghiệm.

\section{II. ĐỐI TƯƠNG VÀ PHƯƠNG PHÁP NGHIÊN CỨU \\ 2.1.Thời gian và địa điểm nghiên cứu:} Nghiên cứu được thực hiện tại Trung tâm nghiên cứu lâm sàng thuộc Viện Ung thư quốc gia và Trung tâm Dược lý lâm sàng, trường Đại học $Y$ Hà Nội trong khoảng thời gian từ 1/10/2019 30/7/2020.

2.2. Nguyên liệu và đôi tượng nghiên cứu:

- Thuốc nghiển cứu: 3500 Viên nang cứng Fucolen. Mẫu số 1, công thức M1813568 bào chể ngày 20/12/2019. Thành phần: Fucoidan $105 \mathrm{mg}$, Lentinan $60 \mathrm{mg}$, Lactose, agnesium stearate, vỏ nang gelatin vửa đủ 1 viên nang cứng $600 \mathrm{mg}$. Liều dùng dự kiến trên lâm sàng: 4 viên/ngày

- Động vật thực nghiệm: Chuột cống trắng chủng Wistar, cả hai giống, khỏe mạnh, cân nặng $160 \pm 20 \mathrm{~g}$. Động vật được nuôi 5-7 ngày trước khi nghiên cứu và trong suốt thời gian nghiên cứu trong điêu kiện phòng thí nghiệm với đây đủ thức ăn và nước uống tại Bộ môn Dược lý, Trường Đại học $Y$ Hà Nội.

\subsection{Phương pháp nghiên cứu}

2.3.1. Thiết kế nghiên cứu: nghiên cứu thực nghiệm

\subsubsection{Máy móc phục vụ nghiên cứu}

*Hóa chất nghiên cứu:

- Kít định lượng các enzym và chất chuyển hóa trong máu: ALT (alanin aminotransferase), AST (aspartat aminotransferase), bilirubin toàn phần, albumin, cholesterol toàn phần, creatinin của hãng Erba (Đức).

- Các hóa chất xét nghiệm và làm tiêu bản mô bệnh học.

*Dụng cụ nghiên cứu:

- Máy xét nghiệm sinh hóa bán tự động Erba Chem 5 V3 của Đức.

- Máy xét nghiệm huyết học ABX Micros ES 60 của Pháp.

2.3.3. Chỉ số nghiên cứu: Các chỉ tiêu theo dõi trước và trong quá trình nghiên cứu:

- Tình trạng chung, thể trọng của chuột cống trắng.

- Đánh giá chức năng gan thông qua định lượng một số chất chuyển hoá trong máu: bilirubin toàn phần, albumin và cholesterol toàn phần.

- Đánh giá mức độ tổn thương tế bào gan thông qua định lượng hoạt độ enzym trong máu: AST, ALT.

- Đánh giá chức năng thận thông qua định lượng nồng độ creatinin huyết thanh.

- Mô bệnh học: Sau 12 tuần uống thuốc, chuột cống trắng được mổ để quan sát đại thế toàn bộ các cơ quan. Kiểm tra ngẫu nhiên cấu trúc vi thể gan, thận của 30\% số chuột cống trắng ở mỗi lô. Các xét nghiệm vi thể được thực hiện tại Trung tâm Nghiên cứu và phát hiện sớm ung thur.

2.3.4. Quy trình nghiên cứu: Nghiên cứu độc tính bán trường diễn đường uống trên chuột cổng trắng được tiến hành theo hướng dẫn của Tổ chức $Y$ tế thế giới về thuốc có nguồn gốc dược liệu. Chuột cống trắng được chia làm 3 lô, mỗi lô 10 con.

+ Lô 1 (chứng sinh học) ( $n=10)$ : uống dung môi pha thuốc $10 \mathrm{ml} / \mathrm{kg} / \mathrm{ngày}$

+ Lô trị $1(n=10)$ : uống Fucolen liều 0,48 viên $/ \mathrm{kg} / \mathrm{ngày}$ (liều có tác dụng tương đương liêuu dự kiến trên người, tính theo hệ số 6 ).

+ Lô trị $2(n=10)$ : uống Fucolen liều 1,44

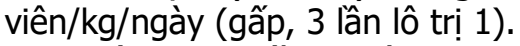

Chuột được uống nước hoặc thuốc thử trong 12 tuần liên tục, mỗi ngày một lần vào buổi sáng. Các thông số theo dõi được kiểm tra vào trước lúc uống thuốc, sau 4 tuần, 8 tuần và sau 12 tuần uống thuốc.

2.4. Xử lý số liệu: Số liệu được nhập bằng phần mềm Epidata 3.1, phân tích số liệu và phân tích sự khác biệt bằng T-test (Stata 11.0). Các số liệu nghiên cứu được thu thập và xử lý bằng phương pháp thống kê y sinh học theo t-testStudent và test trước sau (Avant-après). Biểu diễn dưới dạng $\bar{X}^{\bar{X}} \pm \mathrm{SD}$. Sự khác biệt có ý nghĩa thống kê khi $p<0,05$.

2.5. Đạo đức trong nghiên cứu: Nghiên cứu được chấp thuận bởi Hội đồng đạo đức nghiên cứu y sinh học, Bệnh viện $K$ theo quyết định số 563/BVK - HĐĐĐ và tuân thủ chặt chẽ các quy trình.

\section{KẾT QUẢ NGHIÊN CỨU VÀ BÀN LUÂN}

Trong thời gian thí nghiệm, chuột ở các lô hoạt động bình thường, nhanh nhẹn. Tuy nhiên, sau uống thuốc 1 tuần ở lô uống Fucolen liều cao chuột xuất hiện tiêu chảy và kéo dài 5 ngày. Các 
tuần tiếp theo chuột ăn uống tốt, không bị tiêu chảy. Lô uống Fucolen liều thấp chuột ăn uống

tốt, phân khô trong suốt thời gian nghiên cứu.

Bảng 1. Ảnh hưởng của Fucolen đến hoạt độ AST (GOT) trong máu chuột

\begin{tabular}{|c|c|c|c|c|}
\hline \multirow{2}{*}{ Thời gian } & \multicolumn{3}{|c|}{ Hoat đô AST (UI/I) } & \multirow{2}{*}{$\begin{array}{l}\text { P (t-test } \\
\text { Student) }\end{array}$} \\
\hline & Lô chứng & Lô trị 1 & Lô trị 2 & \\
\hline Trước uống thuốc & $105,80 \pm 29,17$ & $106,60 \pm 12,73$ & $98,00 \pm 15,51$ & $>0,05$ \\
\hline Sau 4 tuân uống thuốc & $87,40 \pm 22,16$ & $108,10 \pm 27,66$ & $86,13 \pm 19,91$ & $>0,05$ \\
\hline $\mathbf{p}($ trước - sau) & $>0,05$ & $>0,05$ & $>0,05$ & \\
\hline Sau 8 tuân uống thuốc & $90,20 \pm 19,15$ & $89,70 \pm 21,59$ & $90,50 \pm 21,99$ & $>0,05$ \\
\hline $\mathbf{p}($ trước - sau) & $>0,05$ & $>0,05$ & $>0,05$ & \\
\hline Sau 12 tuân uống thuốc & $81,50 \pm 23,02$ & $93,40 \pm 18,51$ & $85,63 \pm 21,82$ & $>0,05$ \\
\hline $\mathbf{p}($ trước - sau) & $>0,05$ & $>0,05$ & $>0,05$ & \\
\hline
\end{tabular}

Kết quả ở các bảng 1 cho thấy: sau 4 tuần, 8 tuần và 12 tuần uống Fucolen, xét nghiệm đánh giá mức độ tổn thương tế bào gan thông qua hoạt độ AST trong máu chuột ở lô trị 1 (uống Fucolen liều 0,48 viên $/ \mathrm{kg} / \mathrm{ngày}$ ) và lô trị 2 (uống Fucolen liều 1,44 viên $/ \mathrm{kg} / \mathrm{ngày}$ ), không có sự khác biệt có ý nghĩa so với lộ chứng và so sánh giữa hai thời điểm trước và sau khi uống thuốc thử $(p>0,05)$.

Bảng 2. Ảnh hưởng của Fucolen đến hoạt độ ALT (GPT) trong máu chuột

\begin{tabular}{|c|c|c|c|c|}
\hline \multirow{2}{*}{ Thời gian } & \multicolumn{3}{|c|}{ Hoạt độ ALT (UI/I) } & \multirow{2}{*}{$\begin{array}{c}\text { p(t-test } \\
\text { Student) }\end{array}$} \\
\cline { 2 - 5 } & Lô chứng & Lố trị 1 & Lô trị 2 & $>0,05$ \\
\hline Trước uống thuốc & $49,30 \pm 12,37$ & $47,40 \pm 7,92$ & $39,38 \pm 6,80$ & $>0,05$ \\
\hline Sau 4 tuần uống thuốc & $49,60 \pm 18,73$ & $49,00 \pm 9,84$ & $45,50 \pm 10,43$ & \\
\hline p (trước - sau) & $>0,05$ & $>0,05$ & $>0,05$ & $>0,05$ \\
\hline Sau 8 tuâan uống thuốc & $49,70 \pm 14,90$ & $47,40 \pm 8,78$ & $42,38 \pm 10,91$ & \\
\hline p (trước - sau) & $>0,05$ & $>0,05$ & $>0,05$ & $>0,05$ \\
\hline Sau 12 tuần uống thuốc & $39,40 \pm 12,19$ & $41,90 \pm 8,32$ & $51,25 \pm 17,03$ & \\
\hline p (trước - sau) & $>0,05$ & $>0,05$ & $>0,05$ & \\
\hline
\end{tabular}

Sau 4 tuần, 8 tuần và 12 tuần uống Fucolen, xét nghiệm đánh giá mức độ tổn thương tế bào gan (hoạt độ ALT trong máu chuột) ở lô trị 1 (uống Fucolen liêu 0,48 viên $/ \mathrm{kg} / \mathrm{ngày}$ ) và lồ trị 2 (uống Fucolen liều 1,44 viên/ $\mathrm{kg} / \mathrm{ngày}$ ), không có sự khác biệt có ý nghĩa so với lô chứng và so sánh giữa hai thời điểm trước và sau khi uống thuốc thử $(p>0,05)$.

Bảng 3. Ánh hưởng của Fucoilen đến nồng độ bilirubin toàn phân trong máu chuột

\begin{tabular}{|c|c|c|c|c|}
\hline \multirow{2}{*}{ Thời gian } & \multicolumn{2}{|c|}{ Bilirubin toàn phần(mmol/I) } & P (t- test \\
\cline { 2 - 4 } & Lô chứng & Lô trị 1 & Lô trị 2 & Student) \\
\hline Trước uống thuốc & $13,34 \pm 0,54$ & $13,39 \pm 0,35$ & $13,70 \pm 0,39$ & $>\mathbf{0 , 0 5}$ \\
\hline Sau 4 tuần uống thuốc & $13,42 \pm 0,40$ & $13,41 \pm 0,24$ & $13,56 \pm 0,32$ & $>\mathbf{0 , 0 5}$ \\
\hline p (trươớc - sau) & $>0,05$ & $>0,05$ & $>0,05$ & \\
\hline Sau 8 tuần uống thuốc & $13,40 \pm 0,41$ & $13,57 \pm 0,32$ & $13,43 \pm 0,32$ & $>\mathbf{0 , 0 5}$ \\
\hline p (trước - sau) & $>0,05$ & $>0,05$ & $>0,05$ & \\
\hline Sau 12 tuần uống thuốc & $13,40 \pm 0,54$ & $13,47 \pm 0,44$ & $13,50 \pm 0,26$ & $>\mathbf{0 , 0 5}$ \\
\hline p (trước - sau) & $>0,05$ & $>0,05$ & $>0,05$ & \\
\hline
\end{tabular}

Bảng 3 cho thấy: sau 12 tuần uống Fucolen, xét nghiệm đánh giá chức năng gan nồng độ bilirubin toàn phần trong máu chuột ở cả lô trị 1 (uống Fucolen liều 0,48 viên $/ \mathrm{kg} / \mathrm{ngày}$ ) và lô trị 2 (uống Fucolen liều 1,44 viên/kg/ngày) đều không có sự khác biệt có ý nghĩa so với lô chứng và so sánh giữa hai thời đ̛̣iêm trước và sau khi uống thuốc thử $(p>0,05)$.

Bảng 4. Ảnh hưởng của Fucolen đến nông độ albumin trong máu chuột

\begin{tabular}{|c|c|c|c|c|}
\hline \multirow[b]{2}{*}{ Thời gian } & \multicolumn{3}{|c|}{ Albumin $(g / d l)$} & \multirow{2}{*}{$\begin{array}{l}\text { P (t-test } \\
\text { Student) }\end{array}$} \\
\hline & Lô chứng & Lô trị 1 & Lô trị 2 & \\
\hline Trước uống thuốc & $3,59 \pm 0,24$ & $3,43 \pm 0,38$ & $3,36 \pm 0,39$ & $>0,05$ \\
\hline Sau 4 tuần uống thuốc & $3,43 \pm 0,32$ & $3,38 \pm 0,42$ & $3,25 \pm 0,27$ & $>0,05$ \\
\hline $\mathbf{p}($ trước - sau) & $>0,05$ & $>0,05$ & $>0,05$ & \\
\hline Sau 8 tuần uống thuốc & $3,39 \pm 0,30$ & $3,18 \pm 0,33$ & $3,14 \pm 0,37$ & $>0,05$ \\
\hline p (trước - sau) & $>0,05$ & $>0,05$ & $>0,05$ & \\
\hline Sau 12 tuân uống thuốc & $3,33 \pm 0,29$ & $3,61 \pm 0,32$ & $3,33 \pm 0,36$ & $>0,05$ \\
\hline $\mathbf{p}($ trước - sau) & $>0,05$ & $>0,05$ & $>0,05$ & \\
\hline
\end{tabular}


Bảng 4 cho thấy: xét nghiệm đánh giá chức năng gan nồng độ albumin trong máu chuột ở lô trị 1 và lô trị 2 không có sự khác biệt có ý nghĩa so với lô chứng và so sánh giữa hai thời điểm trước và sau khi uống thuốc thử 12 tuần ( $p>0,05)$.

Bảng 5. Ánh hưởng của Fucolen đến nồng đô cholesterol toàn phần trong máu chuôt

\begin{tabular}{|c|c|c|c|c|}
\hline \multirow{2}{*}{ Thời gian } & \multicolumn{2}{|c|}{ Cholesterol toàn phân (mmol/I) } & \multirow{2}{*}{$\begin{array}{c}\text { P (t- test } \\
\text { Student) }\end{array}$} \\
\cline { 2 - 4 } & Lô chứng & Lô trị 1 & Lô trị 2 & $>0,05$ \\
\hline Trước uống thuốc & $1,81 \pm 0,22$ & $1,74 \pm 0,28$ & $1,69 \pm 0,25$ & $>0,05$ \\
\hline Sau 4 tuần uống thuốc & $1,65 \pm 0,23$ & $1,72 \pm 0,30$ & $1,53 \pm 0,24$ & \\
\hline p (trước - sau) & $>0,05$ & $>0,05$ & $>0,05$ & \\
\hline Sau 8 tuần uống thuốc & $1,64 \pm 0,38$ & $1,91 \pm 0,21$ & $1,58 \pm 0,25$ & $>0,05$ \\
\hline $\mathbf{p}$ (trước - sau) & $>0,05$ & $>0,05$ & $>0,05$ & \\
\hline Sau 12 tuần uống thuốc & $1,86 \pm 0,39$ & $1,88 \pm 0,30$ & $1,71 \pm 0,34$ & $>0,05$ \\
\hline p (trước - sau) & $>0,05$ & $>0,05$ & $>0,05$ & \\
\hline
\end{tabular}

Kết quả ở bảng 5 cho thấy cho thấy: Tại thời điểm sau 4 tuần, 8 tuần và 12 tuần uống Fucoilen xét nghiệm đánh giá chức năng gan nồng độ cholesterol toàn phần trong máu chuột cả lô trị 1 (uống Fucoilen liều 0,48 viên $/ \mathrm{kg} / \mathrm{ngày}$ ) và lô trị 2 (uống Fucoilen liều 1,44 viên/ $\mathrm{kg} / \mathrm{ngày} \mathrm{không} \mathrm{có} \mathrm{sự} \mathrm{khác}$ biệt có ý nghĩa so với lô chứng và so sánh giữa hai thời điểm trước và sau khi uống thuốc thử 12 tuần $(\mathrm{p}>0,05)$.

Bảng 6. Ánh hưởng của Fucoilen đến nồng độ creatinin trong máu chuột

\begin{tabular}{|c|c|c|c|c|}
\hline \multirow{2}{*}{ Thời gian } & \multicolumn{3}{|c|}{ Creatinin (mg/dl) } & \multirow{2}{*}{$\begin{array}{l}\text { P (t- test } \\
\text { Student) }\end{array}$} \\
\hline & Lô chứng & Lô trị 1 & Lô trị 2 & \\
\hline Trước uống thuốc & $0,81 \pm 0,22$ & $0,75 \pm 0,16$ & $0,84 \pm 0,13$ & $>0,05$ \\
\hline Sau 4 tuần uống thuốc & $0,88 \pm 0,18$ & $0,84 \pm 0,15$ & $0,86 \pm 0,12$ & $>0,05$ \\
\hline $\mathbf{p}($ trước - sau) & $>0,05$ & $>0,05$ & $>0,05$ & \\
\hline Sau 8 tuần uống thuốc & $0,72 \pm 0,11$ & $0,80 \pm 0,14$ & $0,79 \pm 0,19$ & $>0,05$ \\
\hline p (trước - sau) & $>0,05$ & $>0,05$ & $>0,05$ & \\
\hline Sau 12 tuân uống thuốc & $0,74 \pm 0,13$ & $0,82 \pm 0,14$ & $0,81 \pm 0,14$ & $>0,05$ \\
\hline $\mathbf{p}($ trước - sau) & $>0,05$ & $>0,05$ & $>0,05$ & \\
\hline
\end{tabular}

Bảng 6 cho thấy: sau 12 tuần uống Fucolen, ở cả lô trị 1 (uống Fucolen liều 0,48 viên/ $\mathrm{kg} / \mathrm{ngày}$ ) và lô trị 2 (uống Fucolen liều 1,44 viên $/ \mathrm{kg} / \mathrm{ngày}$ ), nồng độ creatinin trong máu chuột không có sự khác biệt có ý nghĩa thống kê so với lô chứng và so sánh giữa hai thời điểm trước và sau khi uống thuốc thử $(p>0,05)$.

*Hình ảnh đại thể và vi thể cơ quan sau 12 tuần nghiên cứu

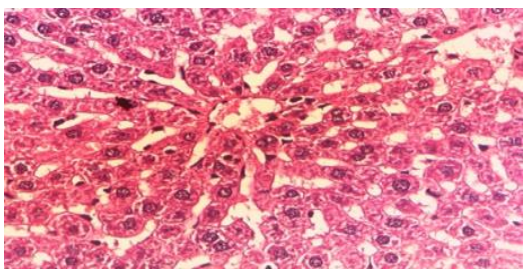

Hình ảnh vi thể gan chuôt lô chứng

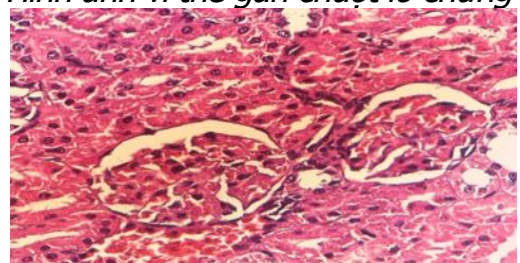

Hình ảnh vi thể thận chuột lô chứng

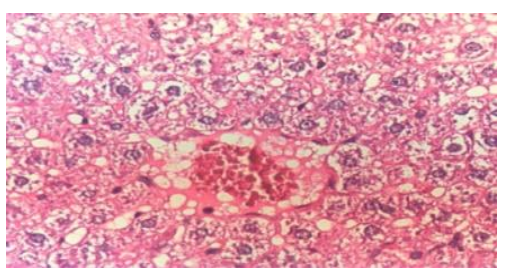

Hinh ảnh vi thể gan chuột lô trị 1

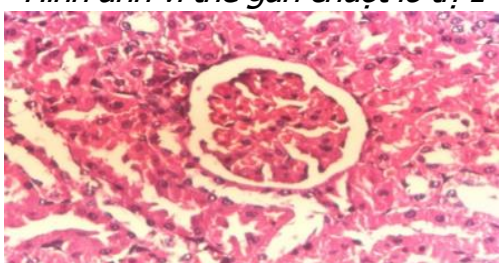

Hình ảnh vì thể thân chuột lô chứng 1 nghiên cứu (lô chứng và 2 lô tri) khố thấy có thay đổi bênh lý nào về măt đai thể của các cơ quan: tim, phổi, gan, lách, tụy, thận và hệ thống tiêu hóa của chuột.

- Hình ảnh vi thể gan và thân: không quan sát thấy có thay đổi bênh lý nào về mặt vì thể thể của gan, thân giữa lổ chứng và lô trị. các cơ quan: tim, phổi, gan, lách, tụy, thận và hệ thống tiêu hóa của chuột.

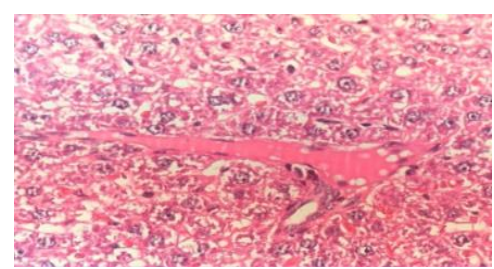

Hình ảnh vi thể gan chuột lô trị 2

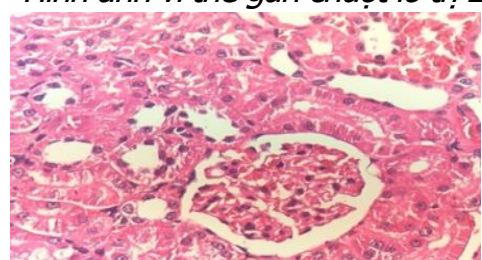

Hình ảnh vĩ thể thận chuột lô chứng 2 


\section{KẾT LUẬN}

Kết quả nghiên cứu độc tính bán trường diễn theo đường uống của viên nang cứng Fucolen cho thây Fucolen liều tương đương liêu dự kiến lâm sàng $(0,48$ viên $/ \mathrm{kg} / \mathrm{ngày})$ không làm ảnh hưởng xấu đến tình trạng chung, trọng lượng của chuột cống trắng tằng so với trước nghiên cứu, sự khác biệt có ý nghĩa thông kê so với lô chứng sau 12 tuân nghiên cứu. Không gây tổn thương tế bào gan (hoạt độ AST, ALT trong máu chuột cống trắng), khống làm thay đổi kết quả nồng độ bilirubin toàn phân, cholesterol toàn phân và albumin trong máu chuột cống trắng so với lô chứng. Không có sự khác biệt rõ ràng về cấu trúc vi thể gan và thận khi so sánh giữa lô trị và lô chứng.

\section{TÀI LIẸU THAM KHẢO}

1. Cuong H.D., Thuy T.T.T., Huong T.T., và cộng sự. Structure and hypolipidaemic activity of fucoidan extracted from brown seaweed Sargassum henslowianum. Nat. Prod. Res. 2015; 29:411-415.

2. Malve H. Exploring the ocean for new drug developments: Marine pharmacology. J. Pharm. Bioallied Sci. 2016; 8:83-91.

3. Kinghorn A.D., Chin Y.W., Swanson S.M. Discovery of natural product anticancer agents from biodiverse organisms. Curr. Opin. Drug Discov. Dev. 2009;12: 189-196.

4. Sanjeewa K.K.A., Kim E.A., Son K.T., và công sư. Bioactive properties and potentials cosmeceutical applications of phlorotannins isolated from brown seaweeds: A review. J. Photochem. Photobiol. B-Biol. 2016; 162:100-105.

5. Cunha L., Grenha A. Sulfated Seaweed Polysaccharides as Multifunctional Materials in Drug Delivery Applications. Mar. Drugs. 2016; 14:42.

6. Sanjeewa K.K.A., Kim E.A., Son K. T. Bioactive properties and potentials cosmeceutica applications of phlorotannins isolated from brown seaweeds: A review. J. Photochem. Photobiol. BBiol. 2016; 162:100-105.

7. Bộ Y tế. Quy chế Đánh giá tính an toàn và hiệu lực thuốc Cố truyền. Quyết định số 371/BYT-QĐĐ ngày 12/3/1996. 1996.

\section{NGHIÊN CỨU ĐĂC ĐIỂM LÂM SÀNG, CÂN LÂM SÀNG UNG THƯ HẠ HỌNG - THANH QUẢN GIAI ĐOẠN III, IVA-B TẠI BỆNH VIỆN UNG BƯỚU NGHÊ AN NĂM 2020}

\section{TÓM TẮT}

Ung thư hạ họng - thanh quản (UTHH-TQ) là loại ung thư tương đối phổ biến, chiếm khoảng $6 \%$ trong các loại ung thư vùng đầu cổ. Bệnh không những ảnh hưởng trầm trong đến các chức năng thở, nuốt và nói mà còn nguy hại đến tính mạng. Nếu được phát hiện sớm và điêu trị kịp thời có thể ha thấp tỉ lệ tử vong một cách đáng kê. Mục tiêu: Mô tả một số đặc điểm lâm sàng, mô bênh hơc UTHH-TQ giai đoạn III, IVA-B. Đánh giá hình thái tổn thương UTHH-TQ qua nội soi. Đối tượng và phương pháp nghiên cứu: 53 người bệnh và 48 hồ sơ bệnh án UTHH-TQ giai đoạn III, IVA-B tại bênh viện Ung bướu Nghệ An từ tháng 01/2020 đến hết tháng 12/2020. Phương pháp nghiên cứu: Thu thập số liệu thông tin thứ cấp trên 48 bênh án, khám và hỏi trên 53 người bênh. Kết quả: Chỉ số toàn trang (PS) chủ yếu $P S=1(64,4 \%)$; rối loạn nuốt $93 / 101(92,1 \%)$, nổi hach cổ 74/101 $(73,3 \%)$, khàn tiếng $21 / 101(20,8 \%)$. Giai đoạn bệnh chủ yếu giai đoạn IV 70/101 (79,3\%). Mô bệnh học:

${ }^{1}$ Bệnh viện Ung bướu Nghệ An

Bê̂nh viện $K$

Chiu trách nhiêm chính: Thái Đình Hiếu

Email: Thaihieutbmu@gmail.com

Ngày nhân bài: 15.01.2021

Ngày phản biên khoa học: 15.3.2021

Ngày duyệt bài: 25.3.2021
Thái Đình Hiếu', Nguyễn Tiến Quang ${ }^{2}$

$100 \%$ ung thư biểu mô tế bào vảy có độ mô học II và III. Ung thư hạ họng - thanh quản chủ yếu xuất phát từ xoang lê $82 / 101(81,2 \%)$. Thể sùi gặp nhiều nhất $70 / 101(69,3 \%)$.

Tư khóa: Ung thư ha họng - thanh quản; đăc điểm lâm sàng, cận lâm sàng.

\section{SUMMARY}

RESEARCH CLINICAL AND SUBCLINICAL CHARACTERISTICS OF STAGE III, IVA-B HYPOPHARYNGEAL AND LARYNGEAL CANCER IN NGHE AN ONCOLOGY HOSPITAL IN 2020

Hypopharyngeal and laryngeal cancer is a common cancer, accounting for approximately $6 \%$ of head and neck carcinoma. The disease is not only seriously affecting to the functions of breathing, swallowing and speaking but also life-threatening. If the disease is detected and treated early, it can reduce significantly the incidence of mortality. Objective: To describe some clinical characteristics, histopathology of stage III, IVA-B hypopharyngeal and laryngeal cancer. To assess morphological leisions of hypopharyngeal and laryngeal cancer by endoscopy. Patients and methods: 101 patients with stage III, IVA-B hypopharyngeal and laryngeal cancer recieved neoadjuvant chemotherapy or chemoradiotherapy in Nghe An Oncology hospital from January 2020 to December 2020. Method: Data collection on 48 medical records and 53 patients. Results: $P S=1$ is 